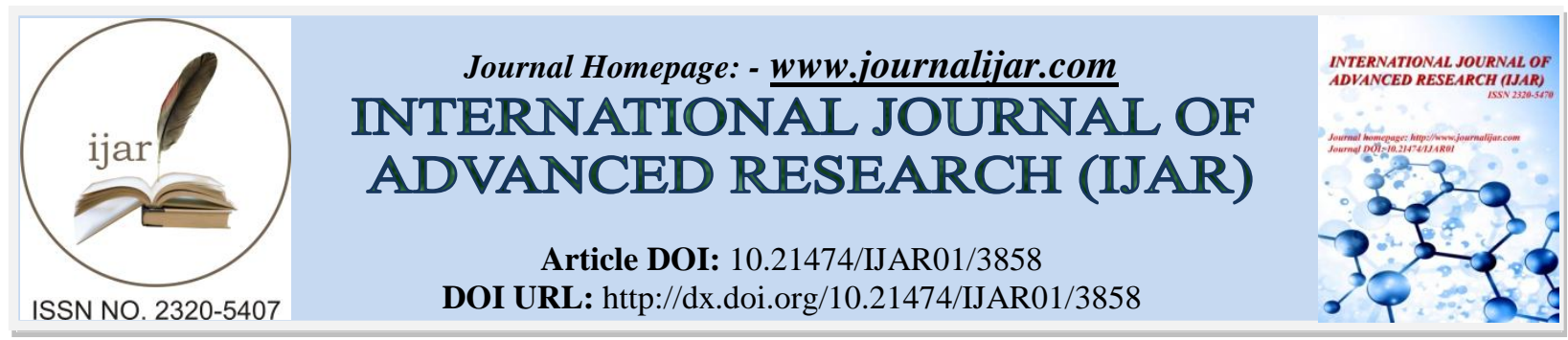

RESEARCH ARTICLE

\title{
A STUDY ON PLASMA TREATED BAMBOO/COTTON BLENDED FABRIC FOR ASSESSING ANTIBACTERIAL ACTIVITY IN NANO ENCAPSULATED TEXTILES.
}

\author{
Banupriya. J Mphil Ph.D ${ }^{1}$ and Dr. V. Maheshwari M. Phil. Ph.D ${ }^{2}$. \\ 1. (Ph.D scholar), PSG College of arts and science, Coimbatore. \\ 2. Guide and Associate professor, PSG College of arts and science, Coimbatore.
}

\section{Manuscript Info}

Manuscript History

Received: 08 February 2017

Final Accepted: 09 March 2017

Published: April 2017

Key words:-

Plasma, nano encapsulation, antibacterial finish, herbal extract.

\begin{abstract}
The plasma is the one of technique which enables to modify the surface structure of textile materials. This paper focuses on the effect of plasma treatment applied on rechargeable antibacterial finishing for bamboo/cotton woven fabrics. The fabric was exposed to plasma treatment at optimized conditions to increase the hydrophilicity. The plasma treated fabric was then finished with herbal nano encapsulation process for textile application. The antibacterial properties of woven fabrics treated with herbal extracts were tested against E.coli and S.aureus by using ENISO 20645 standard method. The plasma treated bamboo/cotton woven fabrics finished with plant extract was compared with untreated plasma finished fabric. The characterization of the functional changes due to the plasma treatment has been carried out by means of FTIR and air permeability test. The result confirmed that the plasma treated nano encapsulation antibacterial coated fabrics showed the higher hydrophilicity.
\end{abstract}

Copy Right, IJAR, 2017,. All rights reserved.

\section{Introduction:-}

Plasma is quite a new technology for the textile industry. It offers an attractive way to add new functionalities. The plasma is an ionized gas with equal density of positive and negative charges which exist over an extremely wide range of temperature and pressure. It is a gaseous state of matter that contains excited species, such as ions, free electrons, and large amounts of visible, UV, IR radiation ${ }^{1}$.

Nanotechnology also has real commercial potential for the textile industry. This is mainly due to the fact that conventional methods used to impart different properties to fabrics often do not lead to permanent effects, and will lose their functions after laundering or wearing. Nanotechnology can provide high durability for fabrics, because nano-particles have a large surface area-to-volume ratio and high surface energy, thus presenting better affinity for fabrics and leading to an increase in durability of the function ${ }^{2}$.

'Sustainability' in textiles refers to the use and refinement of environmental friendly methods in the production of fabrics. This means establishing practices that conserve energy and natural resources and minimize negative environmental, economic and social effects ${ }^{4}$.

Textile materials tend to act as a good medium for the growth and multiplication of microorganisms. The basic chemical constituents present in the natural fibers provide nutrition to microorganisms and thereby promote their 
growth. The growth of microorganisms in the textile materials cause innumerable problems such as unacceptable odor, loss of strength in fabric, and stains and, moreover, affect the health of the wearer ${ }^{3}$.

In recent years, all over the world consumers are demanding for high performance from the textile industries. The prevention of microbial attack on textiles has become increasingly important to consumers and textile producers. The antimicrobial compounds from the plant origin have therapeutic potential as they are effective against numerous infectious diseases. The finishing of natural compounds would be a best alternative for the synthetic antimicrobial agents and heavy metals on the hygienic health care textiles ${ }^{5}$.

The present investigation aims to develop the natural antibacterial finish for textile application. In this study, the bamboo/cotton woven fabric was pre-treated then plasma is applied to increase the rate of hydrophilicity. Then the herbal extract was added to nano capsules and then coated on the plasma pre-treated and untreated bamboo/cotton fabric and their efficiency was checked using ENISO 20645 standard methods.

\section{Material and Methods:-}

\section{Materials:-}

The 30's count bamboo/cotton yarn with plain weave was selected for the study.

\section{Pre-treatment:-}

\section{Desizing:-}

The cotton/bamboo blended woven specimens of 20 grams (approximately $30 \times 30 \mathrm{~cm}^{2}$ ). Mix the fabric in a liquor ratio of $300 \mathrm{ml}$ of buffer. Add $50 \%$ of the commercial enzyme (cellulase) preparations. Maintain the pH of the reaction liquor at $6-7$. Perform the treatment at $50-70^{\circ} \mathrm{C}$ for 60 mins.

\section{Bioscouring:-}

The Desized Cotton/bamboo blended woven fabric was immersing in the commercial bioscouring enzyme solution with $0.05 \mathrm{M}$ phosphate buffer at $55^{\circ} \mathrm{C}, \mathrm{M}$ : L ratio of $1: 50$ for 1 hour. After treatment, raise the temperature to $100^{\circ} \mathrm{C}$ for 10 mins to stop the enzyme action. Wash the fabric in hot water followed by cold water and finally dried.

\section{Bio bleaching:-}

For Square samples $(10 \times 10 \mathrm{~cm})$ of Cotton/bamboo blended woven fabric is taken and placed in $50 \mathrm{ml}$ of $0.1 \mathrm{M}$ phosphate buffer (PH 7.0). Add 20\% of the commercial enzyme cellulase preparations. Mix well and incubate at $50^{\circ} \mathrm{C}$ for $3 \mathrm{~h}$. inactivate the enzyme by boiling to $100^{\circ} \mathrm{C}$ in water for $5 \mathrm{~min}$.

\section{Methods of plasma treatment:-}

Oxygen gas plasma treatment was imparted to the bamboo/cotton fabric in the plasma unit the samples (50X 50 $\mathrm{cms}$ ) were placed on the lower electrode. The chamber was initially evacuated to a base pressure of $5 \times 10^{-2} \mathrm{~m} . \mathrm{bar}$ with the system frequency of $60 \mathrm{KHZ}$ in room temperature.

\section{Herbal nano encapsulation method:-}

\section{Selection of wall and core material:-}

The herbal Michelia X alba leaf extracts prepared were encapsulated using bovine albumin fraction as the wall material and the nano particles as the core material.

\section{Procedure:-}

The herbal extract enclosed bovine serum albumin protein was prepared by coacervation process followed by crosslinking with glutaraldehyde. Michelia X alba leaf extracts was incubated with the required $4 \%$ protein solution $(\mathrm{W} / \mathrm{V})$ for an hour at room temperature. The $\mathrm{pH}$ of the solution was adjusted to 5.5 by $1 \mathrm{M}$ HCL using digital $\mathrm{pH}$ meter. Then ethanol was added to the solution in the ratio of $4: 1(\mathrm{~V} / \mathrm{V})$. The rate of herbal extract addition was carefully controlled at $1 \mathrm{ml}$ per minute. The coacervate so formed was hardened with $25 \%$ glutaraldehyde for 2 hours to allow cross-linking of protein. Organic solvents were then removed under reduced pressure by rotary vacuum evaporator and the resulting nanocapsules were collected and stored for further studies. 


\section{Antibacterial Assessment By En Iso 20645:-}

The antibacterial activity of the Nano encapsulated bleached fabric and Nano encapsulated bleached plasma fabric was tested according to EN ISO 20645 against Staphylococcus aureus and Escherichia coli. Nutrient agar plates were prepared by pouring $15 \mathrm{ml}$ of media into sterile Petri dishes. The plates were allowed to solidify for 5 minutes and $0.1 \%$ inoculum was swabbed uniformly and allowed to dry for 5 minutes. The nano finished bleached and nano finished bleached plasma fabric with the diameter of $2.0 \pm 0.1 \mathrm{~cm}$ was placed on the surface of medium and the plates were kept for incubation at $37^{\circ} \mathrm{C}$ for 24 hours. At the end of incubation, the zone of inhibition formed around the fabrics were measured in millimeters and recorded.

\section{FTIR Analysis:-}

The plasma treated bamboo/cotton fabric has been characterized in order to validate grafting. The fixation of herbal extract on nano encapsulation on the fabric had been realized and the surface chemical composition of bamboo/cotton samples (treated and untreated plasma samples) was studied by FTIR. The spectroscopy was recorded using a thermo Nicolet Avatar 330 instrument in the range of 4000-400 cm-1with a resolution of $4 \mathrm{~cm}-1$ and $\%$ transmittance. The peak at $1242.16,1165,1049.28 \mathrm{~cm}-1$ represented the $\mathrm{C}-\mathrm{N}$ stretch which indicated the presence of aliphatic amines. $=\mathrm{C}-\mathrm{H}$ bend states the presents of alkenes at $941 \mathrm{~cm}-1$. The peak at $802.39,771.53$ and $725.2 \mathrm{~cm}-1$ corresponds to $\mathrm{C}==\mathrm{H}$ of aromatic compounds. The below table represents the FT-IR compounds.

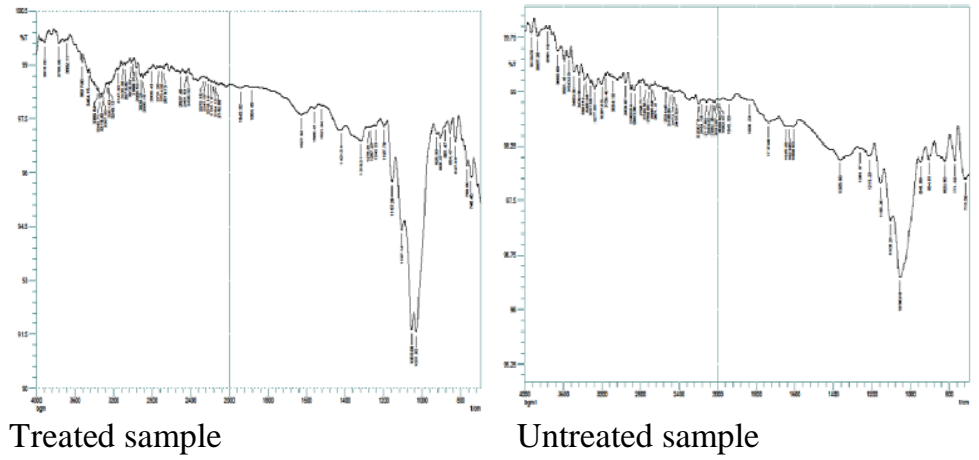

Antibacterial Activity by ENISO 20645:-

\begin{tabular}{|c|c|c|c|}
\hline \multirow[b]{2}{*}{ S. no } & \multirow[t]{2}{*}{ Nano encapsulated Fabric } & \multicolumn{2}{|c|}{ Diameter of zone of inhibition (mm) } \\
\hline & & E.coli & s.aureus \\
\hline 1 & Bleached & $0 *$ & $0 *$ \\
\hline 2 & $\begin{array}{c}\text { Bleached fabric treated with herbal } \\
\text { extract }\end{array}$ & 19 & 22 \\
\hline 3 & $\begin{array}{l}\text { Bleached plasma treated with herbal } \\
\text { extract }\end{array}$ & 23 & 30 \\
\hline
\end{tabular}

*no growth beneath the fabric

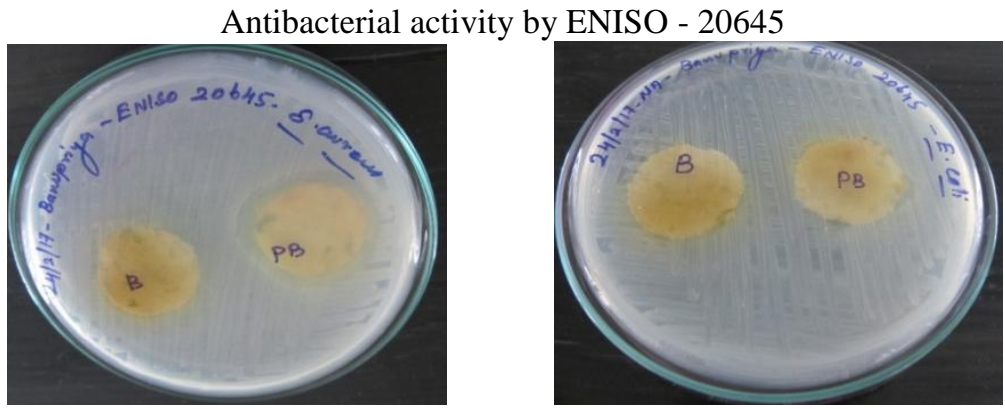

Air permeability:-

PB- Plasma bleached and B-Bleached fabric

\begin{tabular}{|c|c|c|}
\hline Sl.no & Samples & Air permeability \\
\hline 1. & Bleached & 333 \\
\hline 2. & Bleached fabric treated with herbal extract & 303 \\
\hline 3. & Bleached plasma treated with herbal extract & 312 \\
\hline
\end{tabular}


The above Table shows the Air permeability of Bleached, Bleached fabric treated with herbal extract and bleached plasma treated with herbal extract.

\section{Conclusion:-}

Plasma treatments were found to have profound effects on the surface properties of Bamboo/cotton fabrics. Plasma surface treatments without altering the bulky property it shows distinct advantages, beacause they are able to modify the surface properties.

\section{Bibliography:-}

1. Buyle, G., (2009), "Nanoscale Finishing of Textiles via Plasma Treatment", New Cloth Market, Vol. 23, No. 12, December, pp. 39-45

2. C.J.Jahagirdar and L.B.Tiwari, Effect of dichlorodimethylsilane on plasma treated cotton fabric,PramanaJ.Physics.62(5),1099(2004).

3. Gao Y. and Cranston R., 2008, Recent advances in antimicrobial treatments of textiles. Textile Research Journal, 78 (1): 60-72

4. Mercer,. H and Tyndall,.M.R., (2014). "Sustainability in Indigo Dyeing” - International Dyer, issue 3, Published by WTIN. Est.1881. Pp. 34, 37.

5. T. Essawi, M. Srour, "Screening of some Palestinian medicinal plants for antibacterial activity" J. Ethnopharmacol., 2000, 70, pp. 343-349 